\title{
天然鉱物からの放射線誘起ルミネッセンス 現象の基礎研究とその利用
}

(新潟大学理学部) 橋 本 哲 夫

\begin{abstract}
簡便な高感度フィルムを使用したカラー写真撮影により, 放射線照射した火山噴出起源の石英粒子や陶磁器薄片から世: 界に先駆けて青色熱ルミネッセンス以外に赤色熱ルミネッセンス (RTL) 特性を見出した。これらのルミネッセンス特性

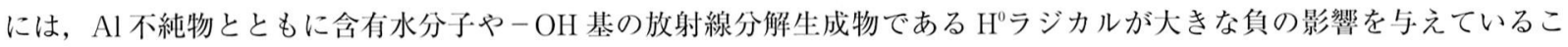
とがわかった。また，石英や長石鉱物に加熱や光照射を行うときのルミネッセンス (発光) 量は，過去に被曝した放射線蓄 積線量に依存しているので，ルミネッセンス年代として, 数十万年より新しい年代測定や人為的被曝線量評価に利用でき ることを確認した。さらに, 石英/長石粒子の RTL 測定用に, 小型 X 線発生装置を搭載したルミネッセンス (R\&BTL/OSL IRSL) 自動測定システムを開発できた。このシステム開発により，遅れがちな我が国の放射線誘起ルミネッセンス分野 の研究が進展することが期待される。本稿では，20数年にわたるルミネッセンス研究の跡をたどるとともに，現状および 将来への展望をも記述する。
\end{abstract}

\section{I .はじめに}

蛍石の加熱に伴う発光(ルミネッセンス)は, 一過(輝 尽)性であることが古くから鉱山関係者の間で広く知ら れており，人類が最初に経験した熱ルミネッセンス (Thermoluminescence: TL) 現象であった。自然放射線 の電離作用で生成した電子のごく一部が鉱物中の格子久 陷や不純物に捉えられ蓄積する。この蓄積捕捉 (捕獲) 電 子が加熱により解放されて, 正孔(ルミネッセンスセン ター)と再結合する際の発光が TLであり, 蛍石以外に 石英や長石など白色鉱物粒子から観測できる。石英粒子 中の蓄積捕捉電子が常温で比較的長い安定性を有するた め, 第二次大戦後, TL 測定による天然蓄積放射線の評 価が可能となり，ルミネッセンス年代測定への利用開発 が行われてきた

加熱以外に光照射による励起 (刺激)により，ルミネッ センス (Optically stimulated luminescence : OSL) が観測 可能であり，蓄積放射線線量評価にも有効なことが1986 年, Huntleyにより見出された。この OSL 現象そのも のは，人工合成ルミネッセンス検出材を用いる放射線検 出用イメージングプレート (IP) と同じ原理であり, 天然 鉱物の IP 的利用に相当している

高感度白黒フィルムによる鉱物粒子からの TL 撮影に 始まった著者らのルミネッセンス研究は, 幸運なこと に, 我が国でのカラーフィルムの高感度化の時期と一致 しており，簡便な TLカラー画像(TL color imaging: TLCI）を最初に公表できた。この TLCI 観察から青色熱 ルミネッセンス (Blue TL : BTL) 以外に, 赤色熱ルミネッ

Basic and Applied Studies of Radiation-Induced Luminescence from Natural Minerals : Tetsuo HASHIMOTO.

(2003年 7 月16日 受理)
センス(Red TL:RTL) 石英粒子が普遍的に存在するこ と発見できた ${ }^{2,35)}$ 。さらに，多彩なルミネッセンス特性 への不純物や加熱温度の影響調查から, 放射線分解生成 物である $\mathrm{H}^{0}$ ラジカルの重要な役割を見出すとともに RTL 測定も可能な小型 X 線発生装置を搭載した高感度 TL/OSL 自動測定システムを開発できだ”。

\section{II . 赤色 TL 石英粒子の発見}

京都大学原子炉実験所から転任して数年目に当たる 1980年代の始め, 新潟大学が位置する砂丘砂から抽出し た石英粒子を，暗室にてヒータ上に載せ加熱に伴う TL を写真撮影していた。撮影に慣れてきたころ，加熱中の 石英粒子から微弱な赤色 TL (RTL)の存在を確認でき た。1980年代初頭はカラーフィルムの高感度化が国内 メーカ間で行われており, 次々に開発発売された高感度 カラーフィルムでの撮影を試みた。その結果, TL カラー 画像(TLCI) から, BTL 粒子以外に, RTLを有する石 英粒子が砂丘砂中に存在することを世界に先駆けて発表 できた8)。

この RTL 石英粒子の発見は, ルミネッセンス研究分 野にとってショックとなり, 数回にわたる LED(第 7 回 学会より Luminescence and ESR Datingが，それまで の ESR and TL Dating に替わって使用されている)年代 測定国際学会でRTL 石英粒子関係の研究は脚光を浴び てきた。このRTL 特性への実験研究が, 天然鉱物から の OSL(励起波長と検出波長をフィルタ弁別して放射線 誘起ルミネッセンスを選択的に検出測定) 現象発見の端 緒ともなった。

第 1 図にいくつかの TLCI を示す。田沢湖の火山噴出 起源の石英粒子は，(a)で見られるように, 典型的な RTL パターンを示しており, 一方, 水晶薄片からはBTL で 

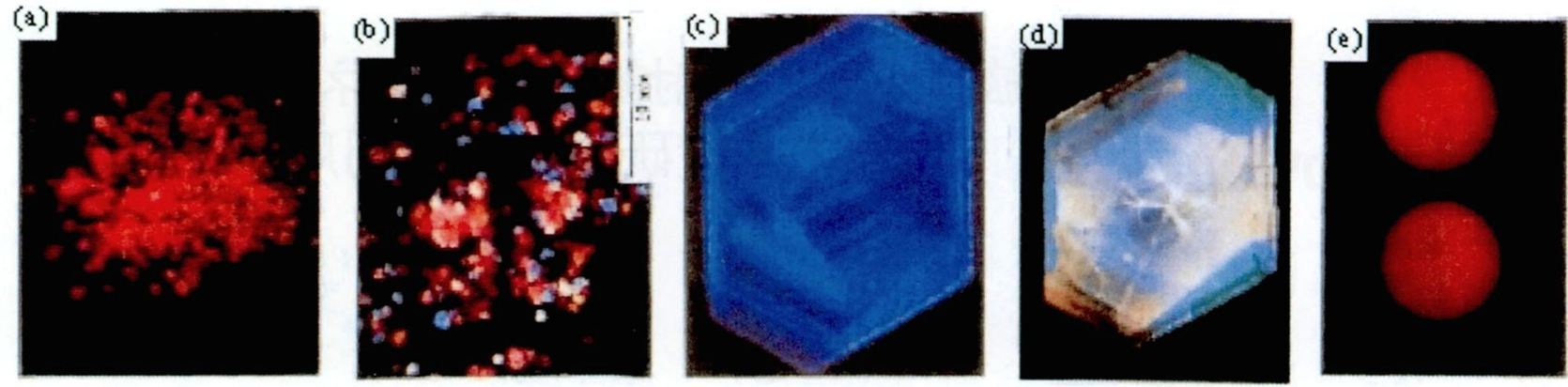

第 1 図 鉱物粒子・薄片等からの熱ルミネッセンスカラー画像 (TLCI)

（a）火山噴出起源石英粒子 (田沢湖产)，（b）新潟海岸砂から抽出した石英粒子，(c) 水晶(マダガスカル産) 薄片，(d) 熱处理済 み水晶薄片 (薄片 (c)を $1,000^{\circ} \mathrm{C} て ゙ 100 \mathrm{~h}$ )，(e) 磁器円板(伊万里)，いずれも数 $\mathrm{kGy}$ 照射後に $80 \sim 400^{\circ} \mathrm{C}$ 温度上昇間暗室にて撮影

(a)

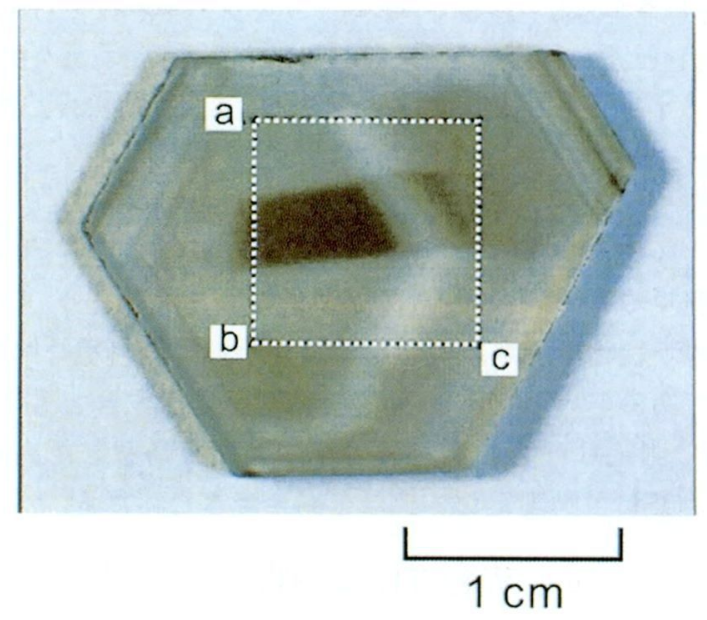

(b)

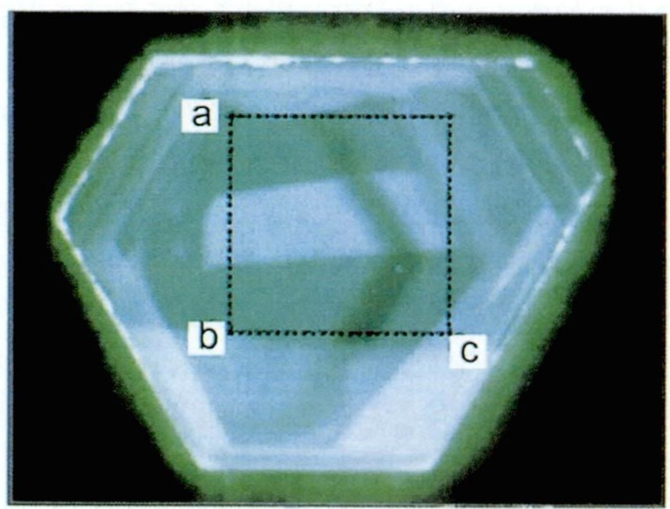

第 2 図水晶薄片 (マダカスカル産)からの放射線誘起カラー センタ画像(a)とBTL 画像(b)。 $\gamma$ 線で20 kGy 照射 後観測

濃淡を示す TLCI (c)パターンが普遍的に得られる(第 2 図(b)からも同様なBTL 濃淡パターンが観察される)。

ところが，新潟砂丘砂石英粒子からはBTL と RTL 混 合粒子からなるTLCI (b)が観察され，熱処理を施した 水晶薄片 $(\mathrm{d})$ の一部分および陶磁器円板 (e)では RTL パ ターンを示しており，これら簡便な撮影に基づく TLCI パターンから定性的な TL 情報が得られることを報告で きだ。
より定量的な情報は，画像増強管を介した極微弱光の オンライン分光器によるTLの 3 次元スペクトル等高線 表示から入手できる。第 3 図に新潟砂丘砂から抽出した 石英粒子からの等高線図を示す。赤・青 2 種類の混合か らなる TLCI (第 1 図(b)) とも一致しており，RTL石英 粒子は $620 \mathrm{~nm}$ 波長域 $320^{\circ} \mathrm{C}$ 付近に TL ピークを有してお り, BTL 石英粒子は $470 \mathrm{~nm}$ 波長域で $200^{\circ} \mathrm{C}$ と $300^{\circ} \mathrm{C}$ 付近 それぞれに強・弱のTL ピークを示す。天然石英はこれ まで例外なく RTLと BTLの 2 種類のみに区別され， RTL 石英粒子は $573^{\circ} \mathrm{C}$ (低温型から高温型への石英の相 転移温度) 以上で生成した高温 $(\beta)$ 型石英に, 一方, BTL 石英粒子は転位温度以下で生成した低温 $(\alpha)$ 型石英へと 起源を同定できた。前者は火山爆発由来の高温からの急 冷で生成された石英(生成時に高温型石英)であり，後者 は花崗岩等の深成岩からの石英や熱水生成の石英 (水晶) 起源であり，いずれも不純物を排除しつつ十分な冷却時 間を経過して生成した石英であると解釈できた。さら

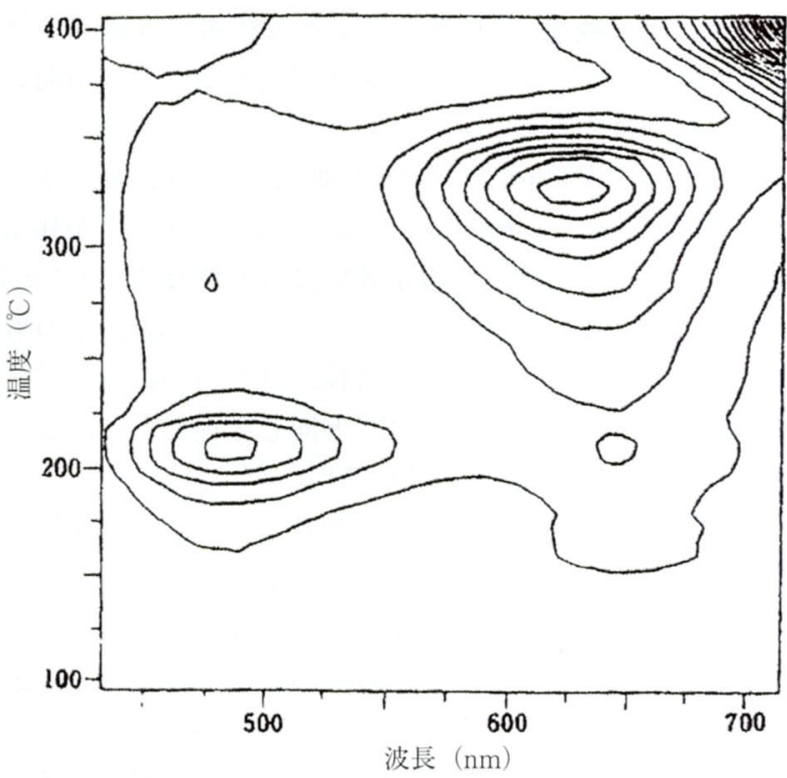

第 3 図 新潟海岸砂より抽出した石英粒子からの TL の 3 次 元 (波長·温度·TL 強度)等高線表示

石英粒子は $\gamma$ 線で $8.7 \mathrm{kGy}$ 照射し加熱しつつ高感度分光器で 連続測定。 
に, BTL 水晶薄片試料を人工的に加熱・冷却 $\left(1,000^{\circ} \mathrm{C}\right.$ から室温まで半日程度)することにより一部分 RTLに 変化して抢り (第 1 図 (d) 参照), 陶磁器からRTL パター ンのみが観察でき(第 1 図(e)), また焼成考古遺物から 抽出した石英粒子もそのほとんどが RTL 特性を有して おり, RTL 特性には高温加熱・急冷が関係しているこ とを見出した。我が国は火山活動の活発な国であり，赤 色 TL 石英粒子の普遍的な観察と調和していた ${ }^{1,5)}$ 。

石英粒子からの青・赤色 TLの熱力学的パラメータ を, 繰り返し昇温・等温壊変法と理論式に基づくグロー カーブを実験で得たグローカーブにフィティングする方 法を用い，活性化エネルギーや頻度因子から関与する捕 捉電子の寿命を評洒した。气の結果, $330^{\circ} \mathrm{C}$ 付近の発光 ではRTLの方がBTLより 1 桁以上安定であり, RTL 測定からは数十万年程度までのルミネッセン久年代測定 が適用可能と見積ることができだ”。

\section{III．ルミネッセンス特性と不純物の関係}

放射線誘起ルミネッセンス特性は $\mathrm{SiO}_{2}$ マトリックス 材に含まれる賦活剤としての不純物原子や格子火陥の性 質を反映している。ゾル・ゲル法で微量不純物を添加し て合成石英ガラスを作製し，ルミネッセンス特性への影 響を調べた。その結果，不純物をドープしない純粋な合 成石英ガラスからは TL は全く観察されず， $\mathrm{Al}$ と Na を 添加した石英ガラスからは不純物濃度に依存した BTL 強度が得られた。

この結果に反して, 天然石英(水晶)試料からの $\mathrm{Al}$ と $\mathrm{Na}$ 不純物濃度 ( $\mathrm{Al}$ : 数 ppm から $150 \mathrm{ppm}$ 程度, $\mathrm{Na}$ 濃 度は $\mathrm{Al}$ のほぼ $1 / 3$ と一定している $\left.{ }^{8}\right)$ と BTL 強度は逆 相関を示しており，石英でのルミネッセンスを含めた放 射線誘起現象が $\mathrm{Al}$ や $\mathrm{Na}$ 不純物濃度のみでは整合性良 い解釈はできなかった。

中性子放射化分析や EPMA (電子プローブマイクロア ナライザ)で検出できない石英中の不純物として, 含有 水分子や- $\mathrm{OH}$ 基を顕微赤外線分光器で調べた。その結 果，第 4 図に示すように, $\mathrm{Al}-\mathrm{OH}\left(3,378 \mathrm{~cm}^{-1}\right.$ 吸収ピー ク)由来のマッピングパターンは, BTL(第 2 四(b))や 水分子由来の $-\mathrm{OH}$ 吸収パターン, さらにはカラーセン 夕濃度の濃淡パターン(第 2 図(a)) とは逆相関を示して いた。 EPMA パターンからの $\mathrm{Al}$ 不純物濃度と $-\mathrm{OH}$ 濃 度は正の相関を有していたことから，放射線誘起現象に $\mathrm{Al}$ と- $\mathrm{OH}$ 不純物が互いに関わりを持つことがわか る。天然石英を低温下 (液体窒素温度)で $\gamma$ 線照射後, 低温測定した ESR スペクトルからは，- $\mathrm{OH}$ や水分子 の放射線分解生成物としての $\mathrm{H}^{0}$ (水素原子)ラジカルと $\mathrm{Al}$ 正孔センターが，いずれも $\mathrm{Al}$ 濃度に正の相関を持っ て検出された。これらのことから, $\mathrm{Al}$ 不純物付近に存 在していた水分子や一 $\mathrm{OH}$ 基の放射線作用で生成した $\mathrm{H}^{0}$ ラジカルが,$-150^{\circ} \mathrm{C}$ 以上では石英中を動くことが可能

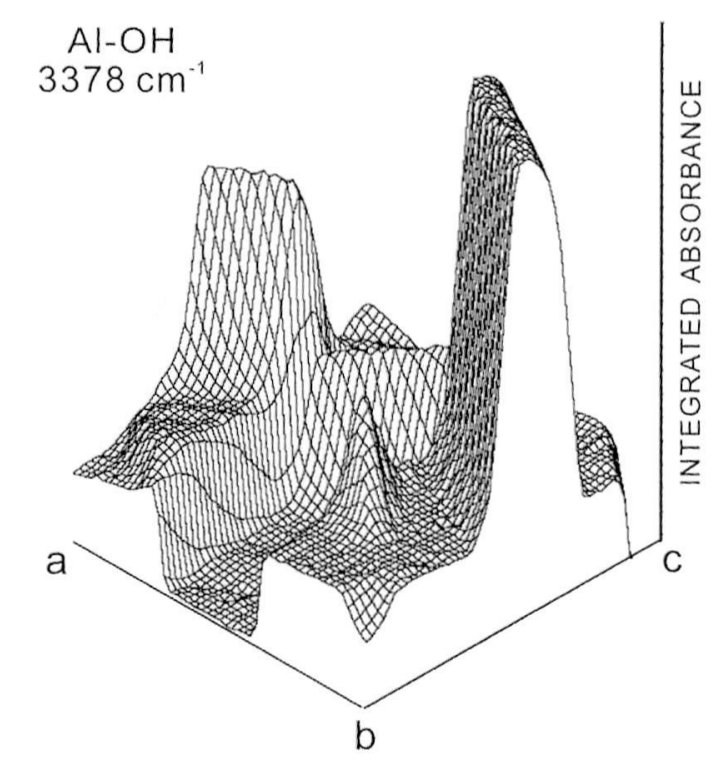

第 4 図 水晶薄片(マダガスカル拳)からの赤外線吸収 $\mathrm{Al}-$ $\mathrm{OH}$ のマッピング

マッピングは第 2 図の正方面 $\mathrm{abc}$ を走查して得た

となり, BTLをもたらす $\mathrm{Al}$ 正孔センタと再結合しセン 夕濃度を減少させるため, $\mathrm{Al}$ 濃度と放射線誘起現象は 逆相関を示すと解釈できだ”。合成石英ガラスを使用す る光通信用のガラスファイバ線では，- $\mathrm{OH}$ 基は微量存 在していても $\mathrm{Al}$ 不純物が全く含有されてないため, 自 然放射線由来のカラーセン夕による経時変化が無視でき るのであろう。

\section{IV. 考古遺物の年代測定や産地分析}

第 5 図に示すように，鉱物生成や焼成作用・太陽光光 曝によりルミネッセンス源がゼロセットされ，その後， 天然放射線や宇宙線が再び作用し，ルミネッセンス源を 蓄積する。この蓄積ルミネッセン久の強さは経過年代と その場での環境放射線線量に対応する。未来へのルミ ネッセンス増加を予測するために数種の年代相当の放射 線線量(放射性核種の化学分析または $\gamma$ 線スペクトロメ トリーや試料採取現場で線量測定器で求める)で人工的

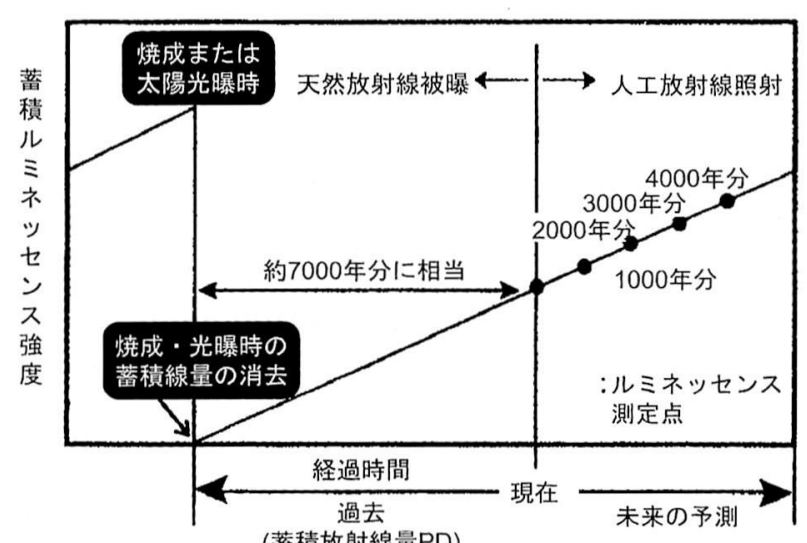

(蓄積放射線量PD)

第 5 図 ルミネッセンス年代測定原理の概念図 
に照射する。照射試料からのルミネッセンス強度を相当 年代值に対してプロットし，これらを通る直線を過去側 に延長してルミネッセンス強度ゼロの横軸との交点が, ゼロセット時以来の年代を与えることになる1”。

このルミネッセンス年代測定法としては現在, TL と OSL 測定法が開発されており, 鉱物試料としては考古 学遺物などから抽出した石英と長石粗粒子や微粒子が用 いられている。近年，同じ石英や長石粒子試料分西を用 いて照射とルミネッセンス測定を繰り返す, 単分画再現 (Single Aliquot Regenerative Dose:SAR) 法の適用が信 頼性高い結果が得られている。

SAR 法を用いた RTL 年代測定法は著者の研究室で初 めて試みられ, 人類学的にも重要な数十万年から100年 程度までをカバーする幅広い絶対年代測定法として認め られてきている。実際に，このRTL年代測定法を，新 潟県柏崎市ナウマンゾウ化石骨や縄文式土器片・須恵器 空跡に適用し, 地質学者や考古学者が地層や文様の様式 などから推定した年代と調和した年代值を得ることがで きた。

捕捉電子の励起を光照射によって行い，励起光を除去 した波長域で放射線由来のルミネッセンスを測定する OSL 年代測定法は, 考古学や人類活動の第四紀と関連 深い堆積層の年代測定に適していることから, 注目され ている。

これらルミネッセンス年代測定の適用範囲としては, 100年程度から数十万年までと広いダイナミックレンジ を有しており, 特に ${ }^{14} \mathrm{C}$ 年代測定が不正確になる 5 万年 以上の年代測定法として期待されている。

TL や OSL 測定は, 天然蓄積線量のみならず，JCO の臨界事故や広島原爆由来の人為的な被曝線量評洒にも 有用であった。

放射線照射直後の燐光としてのアフターグロー (afterglow : AG) も，照射後できるだけ早く暗袋中で市 販のネガカラーフィルムの感光面に押し当てることによ り, 簡便にアフターグローカラー画像 (AGCI)を得るこ とができる。

数地域から採取した古墳時代の須恵器片からの X 線

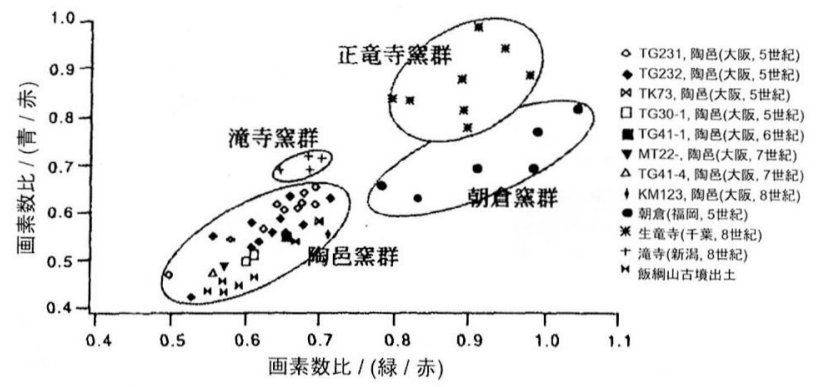

第 6 図 須恵器片より得た AGCI のカラー画像解析を 用いた古窵の群分けと古填出土須恵器片
照射由来の AGCIには，原料である粘土に含まれる長 石の細粒子から多彩な $\mathrm{AG}$ が観察され, 須恵器の産地ご とに異なった発光色パターン分布を示した。AGCI 撮影 フィルムをもとにカラー画像解析を行った結果，第 6 図 に示すように，須恵器古窵ごとに群分けが可能であり， 須恵器の伝播を探る新たな方法として使えることがわ かった。実際に新潟県六日町市の饭綱山古墳群 ( 5 世紀 後半)の10号古墳から出土した須恵器片は, AGCI パター ンからは大阪府堺市の陶邑古案群に属しており, 形式や 文様から予想されていた結果と一致して抢り，考古遺物 の産地や伝播に関する情報を探ることができだ10。

\section{V．ルミネッセンス自動測定システム開発}

実際には，自然界の放射線作用により，鉱物粒子中に 蓄積した捕捉電子や正孔由来の極微弱な TL や OSL · IRSL (赤外光励起ルミネッセンス) を高信頼度で検出 · 測定する必要がある。考古学試料では特に測定鉱物試料 は少なくてすみ，から未来を予測する人工放射線照射も 簡便に行えることが望ましい。そこで，人工放射線照射 による(未来への) ルミネッセンス応答性を調べるため, 放射性同位体 $(\mathrm{RI})$ 線源の替わりに小型 $\mathrm{X}$ 線発生器を搭 載したルミネッセンス自動測定システムを開発した。第 7 図に今回開発したルミネッセンス (TL/OSL) 自動測定 システムの概念図を示す。

RTL を含む TL·OSL 測定のため，加熱体としてセラ ミックスヒータ $(32 \mathrm{~W} \times 4$ 本 $=120 \mathrm{~W}$ 程度の出力とす る)を組み合わせクラスタヒータとして使用すること で，通常の $100 \mathrm{~V}$ 電源使用と温度制御を可能とした。

一方，OSL 測定には，石英と長石の両試料の適用を 目指し，前者は青色の LED (日亜化学製，NSPB 500 S， $470 \mathrm{~nm}$ の青色域にピーク)により励起光を照射し, 後者 は赤外線 (IR) LED (浜松ホトニクス社製，L 2690-02, $890 \mathrm{~nm}$ または L 2388-01，940 nm にピーク)による励起 光を照射できることとした。石英試料からの青色光励起 OSL 測定では， $400 \mathrm{~nm}$ よりも短波長側のルミネッセン 又を適当な光学フィルタで選択測定した。一方, 長石試

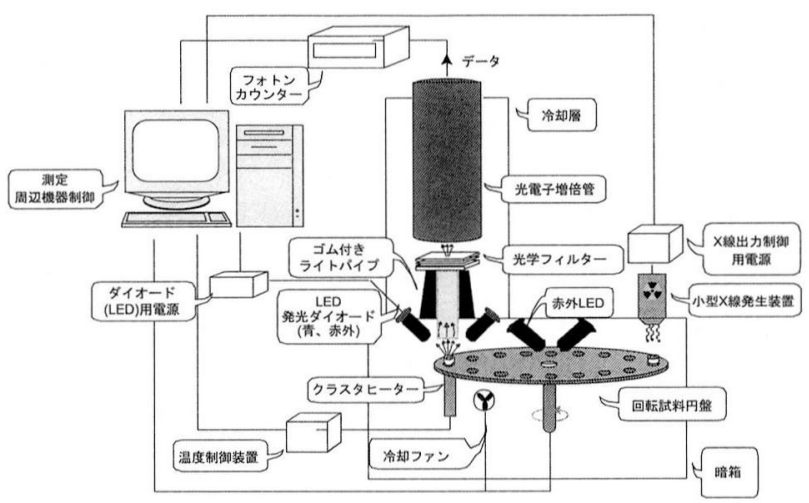

第 7 図 TL/OSL 両用ルミネッセンス自動測定 新システムの概念図 


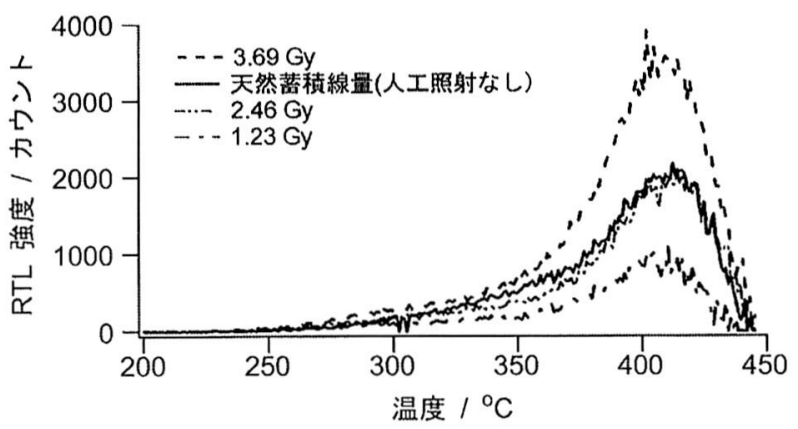

(a)

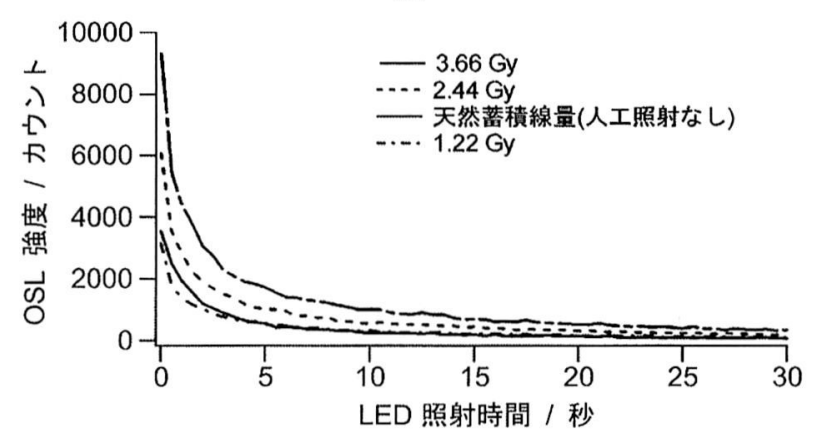

(b)

第 8 図 石英粒子 RTL グローカーブ (a) と OSL 壊変曲線 (b) 新ルミネッセンス自動測定器システムを使用し, 新薬師寺瓦 からの抽出石英粒子に SAR 法を適用

料では IR-LED からの赤外光で励起し, 可視光域 (IRSL と呼ばれる)または赤色域のルミネッセンスが測定でき る仕様とした7)。

第 8 図に本測定システムを用い, 新薬師寺瓦から抽出 した石英粒子にSAR法を適用して得た RTLグロー カーブ (a) と OSL 壊変曲線 (b) を示す。これらの実験曲 線からルミネッセンス線量応答曲線を作成し, 瓦の焼成 以降の蓄積被曝線量を見積もることができた。さらに， 瓦中の放射性核種の $\gamma$ 線スペクトル測定結果と宇宙線 から見積もった年間被曝線量を使用し, ほぼ創建以来の 経過年数に一致した年代值を評価できた。

\section{VI. ルミネッセンス研究の最近の話題と今後}

1990年代の初頭に，中村修二教授が開発した青色発光 の LED (発光ダイオード, 日要化学(株)) からの470 nm にピークを有する光が, 石英粒子の OSL 測定のための 励起 (刺激) 光として最適であり, 今日広く使われてい る。一方, ルミネッセンス感度が高い長石粒子は, IRSL 測定に基づいた年代測定の発展が期待されており, 常温 での自然減衰(フェディング)が無視できる赤色域の IRSL PRT の利用が有望視されており, 現在その方 向に向けての開発が進んでいる ${ }^{11)}$ 。また, 旧石器など考 古遺物の捏造問題を解決するには, 上述の OSL 測定が 最も役立つと考え, 発掘現場での测定を目指したルミ ネッセンス測定器の小型化にも取り組んでいる。
20世紀に物質科学が急速に進展したため，その分野を 専門とする理科系の人々と，文科系や一般の人々との間 に疊瞄を来しており，その溝の拡大傾向は終息する気配 が見られない。21世紀の重要な学問分野の一つとして, この溝を埋める文理融合型の研究分野が位置することは 確かであろう。考古遺物のルミネッセンス年代評価等の 研究は文理融合型研究の自然科学分野からのアプローチ として注目されてきている。これらに加えて, 学生・生 徒や原子力施設周辺部の人々を含めた公采への放射線や 原子力エネルギーのリタラシー教育にもルミネッセンス 研究手法や成果は役立つであろう。

ここでの成果は, 修論・卒論研究等のため研究室に在 席された院生・学部生・研究生および測定システム製作 を手伝って頂いた企業の方々のご協力の賜であります。

関係者の方々に記して梁く感謝申し上げます。

一参考文献一

1）橋本哲夫，さまざまな年代測定・判定法，(6)ルミネッセ ンス法シリーズ「考古学と自然科学」第四卷年代測定学・ 地球科学, 同成社, 84 98(1999).

2) 橋本哲夫, ぶんせき, 296(1994).

3）橋本哲夫, 応用物理, 62, 584(1993).

4) 橋本哲夫, Radioisotopes, 50, 147 (2001).

5）橋本哲夫, 放射線， 26, 25(2000).

6) T. Hashimoto, et al ., Radiat Meas., 33, 431 (2001).

7) T. Hashimoto, et al., J. Nucl. Sci. Technol., 39, 108 (2002).

8) T. Hashimoto, et al., Radiat. Meas., 26, 233 (1996).

9) T. Hashimoto, et al., Radiat. Meas., 27, 243(1997) ; 37. 479 (2003).

10) T. Hashimoto, et al., Ancient TL., 18, 5 (2000).

11) T. Hashimoto, et al., Ancient TL, 21, 1 (2003).

\section{著者紹介}

橋本 哲夫(はしもと・てつお)

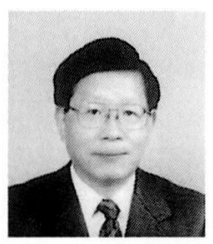

1964年金沢大学理学部化学科卒，66年同大 学院理学研究科修士課程修了。京都大学原 子炬実験所助手。75年新潟大学理学部化学 科助教授を経て 87 年同教授現在に至る。専 門は, 放射化学・環境放射能・放射線計 測・ルミネッセンス応用学。「鉱物を用い た放射線誘起ルミネッセンス現象の新研究 法開発と考古遺物研究への応用」により平 成14年度日本原子力学会賞学術業績賞を受 賞，国立歴史民族博物館兼任教授、原子力 学会関東甲越支部新潟支局長，原子力安全 委員会・環境放射線モニタリング中央評価 分科会副委員長, 新潟県原子力発電所周辺 環境監視評価会議委員などを現在務める。 